\title{
LDO É INSTRUMENTO EFICIENTE PARA A ADMINISTRAÇÃo PÚBLICA
}

Coluna publicada em 9.4.2013:<http://www.conjur.com.br/2013-abr-09/ contas-vista-Ido-instrumento-util-gestao-administracao-publica $>$

Na segunda-feira da semana que vem, dia 15 de abril de 2013, será divulgada a nova Lei de Diretrizes Orçamentárias da União para 2014, o que seguramente, como tem ocorrido todos os anos, será objeto do noticiário, dada a importância que essa lei tem assumido nos últimos anos. A Lei de Diretrizes Orçamentárias - a LDO - foi uma inovação da legislação brasileira, cujo desenho surgiu durante os trabalhos da Assembleia Constituinte, sendo introduzida em nosso ordenamento jurídico pela Constituição de 1988, e seu papel tem sido cada vez mais relevante na condução dos rumos de nossas finanças públicas.

Prevista no artigo $165, \S 2^{\circ}$ da Constituição Federal, tem por função estabelecer anualmente as metas e prioridades da administração pública para as despesas de capital (essencialmente investimentos públicos) e programas de duração continuada. Trata-se de verdadeiro "elo de ligação" entre o plano plurianual, com previsão para quatro anos, e a lei orçamentária, que fixa as receitas e despesas de cada ano. Cumpre função relevante no sistema de planejamento da ação governamental, pois obriga os administradores públicos a definir, a cada ano, quais programas previstos no plano plurianual serão contemplados e quanto se pretende realizar. Evita-se, com isso, o irresistível hábito de "deixar para a última hora", de modo a postergar o cumprimento dos programas para o final do plano plurianual, o que, no mais das vezes, inviabiliza alcançar as metas fixadas, até porque, no último ano do PPA, em regra quem está no exercício do mandato é outro governante (No primeiro ano de mandato não se cumprem promessas, nesta edição, p. 161-164).

Durante os trabalhos da Assembleia Constituinte, aventou-se a possibilidade de um orçamento bianual, válido por dois anos, em substituição ao modelo tradicional, no Brasil e no mundo, de orçamentos anuais. A ideia acabou não vin- 
gando, mas surgiu o projeto de um "pré-orçamento", com vistas principalmente a aumentar a participação do Poder Legislativo na elaboração da lei orçamentária. Definiu-se, portanto, que haveria essa lei, precedendo a lei orçamentária anual, na qual seriam definidas as prioridades e metas da administração pública para o exercício seguinte, orientando a elaboração do orçamento. ${ }^{1}$

Introduzida no texto da Constituição em 1988, a LDO é obrigatória para todos os entes federados e compõe o sistema, uniforme em nossa federação, de planejamento da ação governamental. Estados e municípios diferem da União em alguns detalhes, como o prazo de encaminhamento e aprovação, que atualmente, no âmbito federal, está regulado, ainda provisoriamente, pelo artigo $35, \S 2^{\circ}$, II do ADCT, que determina seja o projeto de lei encaminhado pelo Poder Executivo ao Poder Legislativo "até oito meses e meio antes do encerramento do exercício financeiro e devolvido para sanção até o encerramento da sessão legislativa” - daí a data de 15 de abril que se avizinha. Outros entes federados, por vezes, estabelecem datas diferentes, como é o caso do estado de São Paulo, que prevê o encaminhamento do projeto até o dia 30 de abril (Constituição Estadual, art. 174, $\$ 9^{\circ}, 2$ ).

Desde a promulgação da Constituição, passando pela Lei de Responsabilidade Fiscal, em 2000, até os dias atuais, a Lei de Diretrizes Orçamentárias foi tendo suas atribuiçōos ampliadas, representando um papel cada vez mais importante na organização das finanças públicas, exercendo hoje funções bem maiores do que aquelas inicialmente estabelecidas, de orientação da lei orçamentária e fixação das diretrizes e metas da administração pública.

Já no próprio texto original da Constituição de 1988, vê-se, no artigo 99, $\$ 1^{\circ}$, que compete à LDO, em ação conjunta dos Poderes, estipular os limites financeiros para a apresentação das propostas orçamentárias dos tribunais. Trata-se de um dos mais, se não o mais, relevante instrumento para a plena eficácia da autonomia financeira do Poder Judiciário, pois retira do Executivo a possibilidade de interferir em seu orçamento, uma vez que, ao elaborar sua proposta dentro dos limites da LDO, aprovada pelo Legislativo, não pode ter os valores reduzidos ou modificados por ato do Executivo - o mesmo vale para o Ministério Público (CF, art. $127, \$ 3^{\circ}$ ). Com a Emenda Constitucional 45, de 2009, essa função da LDO estendeu-se também à Defensoria Pública (CF, art. 134, \$2º).

O artigo $165, \$ 9^{\circ}$, da Constituição Federal, previu a edição de lei complementar para dispor sobre o exercício financeiro, a vigência, os prazos, a elaboração e a organização do plano plurianual, da lei de diretrizes orçamentárias e da lei or-

\footnotetext{
Veja-se, neste tema, o trabalho de José Roberto Rodrigues Afonso, Memória da Assembleia Constituinte de 1987/1988: as finanças públicas.
} 
çamentária anual, além de estabelecer normas de gestão financeira e patrimonial da administração direta e indireta, bem como as condições para instituição e funcionamento de fundos. Tal lei complementar ainda não foi publicada, não obstante os vários projetos em andamento (Responsabilidade orçamentária precisa de melhorias, nesta edição, p. 259-262). Com isso, muitas lacunas existem, pois esses assuntos estão sendo regulados pela Lei 4.320/1964, já em vias de completar 50 anos. Suprir essas lacunas tem sido uma função, inúmeras vezes, cumprida pelas leis de diretrizes orçamentárias, como se tem notado ao longo dos últimos anos.

Além disso, em 2000, com a Lei de Responsabilidade Fiscal (Lei Complementar 101, de 5 de maio), que estabeleceu normas de finanças públicas voltadas à responsabilidade na gestão fiscal, a LDO passou a ser importante instrumento de viabilização de normas que pudessem regular e limitar os gastos públicos, o que ampliou sobremaneira seu papel no ordenamento jurídico das finanças públicas. Entre eles, várias merecem destaque.

Regulamentar e estabelecer critérios e forma de limitação de empenho (LRF, art. $4^{\circ}, \mathrm{I}, b$ ), por exemplo, permite que se organize a execução orçamentária, estabelecendo regras e limites, ao contingenciamento, evitando que o Poder Executivo, no exercício de sua função de comando na execução orçamentária, venha a descumprir a lei orçamentária, desviando-a de seu curso, e frustrando a aplicação da lei que havia sido legitimamente aprovada. Coloca, assim, freios aos abusos de há muito observados em matéria orçamentária, em que o Poder Executivo, fazendo uso do contingenciamento, superpõe-se indevida e não democraticamente aos demais Poderes e entes da federação, subjugando-os pela não liberação dos recursos previstos no orçamento.

Estabelecer normas para controle de custos e avaliação dos resultados dos programas orçamentários (LFR, art. $4^{\circ}, \mathrm{I}, c$ ) é fundamental para que se consolide um sistema eficaz de planejamento e orçamento preocupado com o bom desempenho da administração pública, pois permite que se estabeleçam regras claras para avaliação do cumprimento das metas, asfixiando os desvios ilegítimos de recursos públicos pela sua destinação a programas de difícil mensuração, o que sempre facilitou a malversação de dinheiro público.

Fixar condições e exigências para transferências de recursos a entidades públicas e privadas (LRF, art. $4^{\circ}, \mathrm{I}, d$ ) é outro papel da maior relevância, pois a entrega de recursos orçamentários a terceiros, a fim de que atendam a finalidades públicas, é ato que tem se intensificado cada vez mais, da mesma forma que as fraudes que se associam a essa prática. Nada mais relevante do que estabelecer e aperfeiçoar as normas que coíbam esses desvios, no que as LDO têm representado importante papel. 
O Anexo de Metas Fiscais (LRF, art. 4º, $\$ 1^{\circ}$ ), com a fixação de metas para o exercício em curso e os dois subsequentes, a cada ano, é um avanço da legislação em matéria de planejamento, institucionalizando o sistema de "planejamento deslizante" da ação governamental, em que as necessárias alterações e adaptações dessas normas passam a ser feitas de forma gradual e formal, mantendo a segurança jurídica e confiabilidade do sistema. Com a avaliação e acompanhamento das metas estabelecidas, por métodos precisos e transparentes, os gestores ficam impedidos de fazer delas números voltados apenas a cumprir formalidades burocráticas.

O Anexo de Riscos Fiscais (LRF, art. $4^{\circ}, \$ 3^{\circ}$ ) obriga também os administradores públicos a pensar nos problemas futuros, exigindo que se preparem antecipadamente e antecipem as medidas a serem tomadas caso eles venham a se concretizar, evitando as sempre presentes ações imediatas e improvisadas, resolvendo problemas ocorridos e que só tenderão a aumentar, fato mais que conhecido em toda a burocracia estatal.

A exigência de que se divulguem os objetivos das políticas monetária, creditícia e cambial e as metas de inflação (LRF, art. $4^{\circ}, \mathbb{S} 4^{\circ}$ ) tem se mostrado fundamental para a transparência que se espera da administração pública, deixando claro, para os setores público e privado e a sociedade em geral, os rumos que se pretendem dar à ação governamental, o que é fundamental para que todos possam se orientar de forma coordenada e planejada.

Espera-se que se dê mais atenção à Lei de Diretrizes Orçamentárias, inovação do ordenamento jurídico brasileiro que tem se mostrado um instrumento útil e eficiente para o sistema de planejamento, orçamento e gestão da administração pública.

Instrumento esse que colabora de forma decisiva para aquele que seguramente será o maior avanço da administração pública brasileira, que é transformar o gestor público naquele agente que conduz a máquina pública pensando para a frente e que um dia deixará de ser o bombeiro que passa a vida a apagar incêndios. 